Effects of the transition to the RIF of microenterprises in the city of Valle de Santiago, Guanajuato

\title{
Efectos de la transición al RIF de microempresas de la ciudad de Valle de Santiago, Guanajuato
}

\author{
GARCÍA-PICHARDO, Sandra Ivette†*, BÁRCENAS-PUENTE, José Luis, SILVA-CONTRERAS, \\ Juan and MONCADA-MORALES, Jorge Luis
}

\author{
Universidad Tecnológica del Suroeste de Guanajuato. Carretera Valle de Santiago - Huamimaro Km. 1.2, 20 de Noviembre, \\ 38400 Valle de Santiago, Gto.
}

ID $1^{\text {st }}$ Author: Sandra Ivette, García-Pichardo / ORC ID: 0000-0002-0671-7964, CVU CONACYT ID: 745583

ID $1^{\text {st }}$ Coauthor: José Luis, Bárcenas-Puente / ORC ID: 0000-0002-1051-8861, Researcher ID Thomson: 8083 number 58603-2018, CVU CONACYT ID: 743962

ID $2^{\text {nd }}$ Coauthor: Juan, Silva-Contreras / ORC ID: 000-0003-1913-9910, arXiv Author ID: LAJ9UT-QHDDL4, CVU CONACYT ID: 509502

ID $3^{\text {rd }}$ Coauthor: Jorge Luis, Moncada-Morales / ORC ID: 0000-0003-4623-2547, CVU CONACYT ID: 1006998

DOI: $10.35429 / J L E .2019 .5 .3 .31 .40$

Received August 28, 2019; Accepted November 30, 2019

\begin{abstract}
As a measure to reduce tax evasion and informality, the Fiscal Incorporation Regime (RIF) arises with the 2014 tax reform, which generated a radical change in tax obligations and in the way taxpayers must comply, a situation that mainly affects micro and small enterprises, so this work aims to identify the affectations and benefits derived from the incorporation into the RIF of micro-enterprises in the city of Valle de Santiago, Guanajuato. The research is based on a qualitative study, applying the in-depth semi-structured interview technique to 30 taxpayers who have been taxing in the RIF since January 1, 2014. The main results indicate that the tax reform is not entirely negative, the intention of the government of reducing informality has been met, however, the execution has setbacks, as small business owners do not have sufficient fiscal culture or technological preparation to fulfill their obligations on their own, in addition to the fact that the increase in operating expenses represents a strong load for companies, a situation that places them at a disadvantage with respect to their competitors.
\end{abstract}

Fiscal Incorporation Regime, RIF, MSMEs

\begin{abstract}
Resumen
Como una medida para disminuir la evasión de impuestos e informalidad surge con la reforma fiscal de 2014 el Régimen de Incorporación Fiscal (RIF), el cual trajo un cambio radical en las obligaciones fiscales y en la forma en que los contribuyentes deben cumplirlas, situación que afecta principalmente a las micro y pequeñas empresas, por lo que este trabajo tiene como objetivo identificar las afectaciones y beneficios derivados de la incorporación al RIF de microempresas de la ciudad de Valle de Santiago, Guanajuato; se parte de un estudio cualitativo, aplicando la técnica de entrevista semiestructurada a profundidad a 30 contribuyentes que tributan en el RIF desde el 1 de enero de 2014. Los principales resultados señalan que la reforma fiscal no es del todo negativa, la intención del gobierno de reducir la informalidad se ha cumplido, sin embargo, la ejecución tiene contratiempos, pues los dueños de los pequeños negocios no tienen una cultura fiscal ni preparación tecnológica suficiente para cumplir por cuenta propia sus obligaciones, además de que el aumento en los gastos operativos representa una fuerte carga para las empresas, situación que las posiciona en desventaja con respecto a sus competidores.
\end{abstract}

Régimen de incorporación fiscal, RIF, MIPyMES

Citation: GARCÍA-PICHARDO, Sandra Ivette, BÁRCENAS-PUENTE, José Luis, SILVA-CONTRERAS, Juan and MONCADA-MORALES, Jorge Luis. Effects of the transition to the RIF of microenterprises in the city of Valle de Santiago, Guanajuato. Journal-Law and Economy. 2019. 3-5: 31-40.

\footnotetext{
* Correspondence to Author (email: sgarciap@utsoe.edu.mx)

$\dagger$ Researcher contributing as first author.
} 


\section{Introduction}

As part of the Public Administration development plan for the sexennium from 2012 to 2018 , the Fiscal Incorporation Regime was created in the fiscal reform that came into force in 2014 (Cisneros, Bravo, Valenciana, Carrillo and Bustamante, 2016), which it would replace the applicable one for individuals with business activities with annual income of up to 2 million pesos (Intermediate regime), regulated in Section II of Chapter II, of Title IV, as well as REPECOS or small taxpayers, regulated in Section III, of the same Chapter and Title (Vázquez and Gutiérrez, 2018; Manzanero and Castellanos, 2016) that until that moment were exempt from keeping a formal accounting, presenting provisional payments and other fiscal obligations (Villasuso, Bojórquez and De los Santos, 2015 ). Taxpayers who belonged to the previous regime were automatically changed and inserted into the RIF regime by the authority.

With this new RIF scheme, it was intended to reduce the tax evasion that occurred mainly in small taxpayers, as well as give way to fiscal formality, attracting people and companies under a scheme of benefits and administrative facilities, among which the discount is mentioned $100 \%$ of Income Tax in its first year, discounts in Value Added Tax, Special Tax on Production and Services and social security contributions (Vázquez and Gutiérrez, 2019).

At first glance it seemed easier and simpler, however a deeper analysis revealed that the disadvantages may be greater, mainly affecting the MSMEs that were taxed in the Small Taxpayers Regime, some of the reasons that explain this fact are, the scarce and unequal control, low levels of trust in the government, low levels of tax collection, the tax burden imposed on the taxpayer, the complexity of Mexican tax legislation, the poor technological knowledge of these economic units, among others (Villasuso et al. , 2015).
When observing the controversy that exists around the fiscal reform of 2014 with the emergence of the RIF and the implications that it has brought for small taxpayers, which despite the benefits posed by the new regime, could fall into the most unfavorable scenario of unsubscribe or close your business because of the disadvantages that it generates, this research is aimed at identifying the main effects and benefits of microenterprises in the city of Valle de Santiago, Guanajuato, derived from its incorporation into the RIF.

The structure of the present study is as follows. The theoretical framework of the work is described; The methodology presents the type of study to be carried out and the context in which it is located, the data collection technique used and the operationalization of variables; in the next section the results are indicated to finally include in the conclusions section.

\section{Theoretical framework}

\section{Background of the RIF, 2014 reform}

In 2014, the Fiscal Income Tax Regime (RIF) was established in the new Income Tax Law (LISR), which came to replace the Small Taxpayers Regime (REPECOS) (Vázquez and Gutiérrez, 2018); This new scheme emerged as part of the efforts of the Public Administration at that time, whose main objective was to increase the country's productivity, through the participation of all sectors of the population (Arguello, 2014), for the In order to achieve this objective, tax evasion had to be attacked, which according to Castro et al., (2011), the regime with the greatest evasion was precisely REPECO, since it remained virtually unchanged in legislation since its inception in 1996.

The REPECOS regime appears in the year 1996 added in the LISR section III of chapter VI, of title IV for people who performed exclusive operations with the general public, although it was up to two years later (1998) when it appears in the LISR with the name of Small Taxpayers Regime, as it would be known until it was repealed in 2014 (Manzanero and Castellanos, 2016). 
Over the years this regime was evolving mainly at the applicable rate for the entire tax, of $2.5 \%$ on gross income from sales or provision of services to the general public in 1998, changed at a single rate of $2 \%$ in 2001 , for 2002 the rate changed to $1 \%$, in 2003 it changes again at rates of 0 to $2 \%$ (Manzanero and Castellanos, 2016).

Among the reforms proposed during the six-year term of President Enrique Peña Nieto as part of the comprehensive plan to boost economic growth in the country, the tax reform was included, so the Congress of the Union approved changes in tax matters, which came into force on January 1, 2014 (Manzanero and Castellanos, 2016); These reforms included the RIF for individuals with business activity with incomes of up to 2 million who dispose of goods or provide services for those who do not require a professional title for their realization and REPECOS with annual income of 2 million pesos that alienate goods or provide services only to the general public (Villasuso et al., 2015; Arguello, 2014).

In the explanatory statement that justified the introduction of the RIF, it is mentioned that in order to increase the capacity of the Mexican State, a change in the tax structure was necessary, so that it will be more equitable in terms of the distribution of the tax burden, incorporating taxpayers that were in the informal sector, it was also argued that it would be a way to simplify the tax provisions to improve voluntary compliance with tax obligations and the registration to the tax register of taxpayers (IMCP, 2015). The RIF allows the transition to tax formality and offers special treatment to taxpayers who meet the requirements for taxation in this and who opt for the regime for 10 years, after this period is expected that the taxpayer has reached maturity and fiscal stability and that transits to the general regime with permanent compliance in this (Cisneros et al., 2016; Vázquez and Gutiérrez, 2014; Arguello, 2014).

\section{Tax Incorporation Regime, definition}

Transitional taxation scheme that replaces the Small Taxpayers Regime and the Intermediate Regime, introduced in the Tax Reform applied as of January 1, 2014 for individuals with business activities and income of less than two million pesos (CCPM, 2018).
This regime arises as an attempt to create new rules that induce people and companies to join formality and regularize their fiscal situation (Lomelí, 2015).

\section{Tax implications of the RIF}

Article 111 of the LISR indicates that the RIF is applicable for individuals with business activity and REPECOS with annual income of 2 million pesos who sell goods or provide services only with the general public, as well as individuals who carry out business activities by coownership, provided that the sum of the income of all the co-owners does not exceed 2 million pesos in the immediately preceding fiscal year, however, in subsequent decrees and resolutions the benefit is extended to:

1.- Individuals with business activity who also earn income from those indicated in Chapters I, III and IV of Title IV; provided that the sum of all the income received in the immediate previous year for these concepts does not exceed the amount of 2 million pesos (DOF, 2015).

2.- Partners or members of legal entities that pay taxes in Title III (non-profit) of the LISR and natural persons that are partners or members of sports associations (Title II of the LISR) that carry out business activities, dispose of assets or lend services for which no professional title is required, provided that the total income obtained from the previous year does not exceed 2 million pesos (DOF, 2014).

3.- Partners and members of the legal persons referred to in article 79, section XIII of the ISR Law, may choose to pay the ISR under the terms of Title IV, Chapter II, Section II of said Law, even and when they receive interest from said legal persons, provided that the total income obtained in the previous fiscal year for interest, for business activities, disposal of goods or provision of services for which no professional title is required for its realization, in its set does not exceed two million pesos (DOF, 2014).

As Arguello (2014) points out, they cannot pay taxes in the RIF in accordance with art. 111 of LISR natural persons: 
- That they have registered in the RFC any activity other than business activities and / or provision of independent professional services,

- That in 2013 they obtained more than 2 million pesos of income for conducting business activities and / or providing independent professional services,

- That require a professional degree to provide these services.

Additionally, according to art 111 of the LISR (2014):

I. The partners, shareholders or members of legal entities or when they are related parties in accordance with Article 90 of the LISR, or when there is a relationship with persons who have taxed under the terms of that section.

II. Taxpayers who carry out activities related to real estate, real estate capital, real estate business or financial activities, except in the case of those who only obtain income by carrying out acts of promotion or personalized demonstration to clients natural persons for the purchase sale of houses room or house, and said clients are also natural persons who do not carry out acts of construction, development, remodeling, improvement or sale of the houses or dwellings.

III. Natural persons who obtain income referred to in this Chapter by concept of commission, mediation, agency, representation, brokerage, consignment and distribution, except in the case of those persons who receive income from mediation or commission and these do not exceed $30 \%$ of your total income. The withholdings that the moral persons make to them for the provision of this service, are considered final payments for this Section.

IV. Individuals who obtain income referred to in this Chapter for public and franchisee shows.

V. Taxpayers who carry out activities through trusts or joint venture.

The characteristics of the new regime are:
Keep vouchers that meet tax requirements, only when a tax voucher has not been issued for the operation.

ニニニニニニニニニニニニニニニニニニニニニン

Record electronic income, expenses, investments and deductions for the year.

டニニニニニニニニニニニニニニニニニニニニー

Deliver tax receipts to customers.

டニニニニニニニニニニニニニニニニニニニニー

Record electronic income, expenses, investments

and deductions for the year.

Submit bimonthly statements of ISR, VAT and

IEPS in which the tax is determined and paid no

later than the 17th day of the month following the one to which the payment corresponds.

レニニニニニニニニニニニニニニニニニニニニニ

I

The term of permanence is ten fiscal years, that is, after ten consecutive years paying taxes in the

RIF, they must pay as a regime of natural persons I

with business and professional activities from the

ㄴニニニニニニニニニニニニニニニニニニニニニ

The income will be accumulated when they are

effectively collected in cash, goods or services, the

authorized deductions will be applied when they are actually paid.

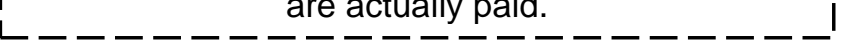

I

Disbursements to be deductible must be paid by I check, credit card, debit card or services when the I amount exceeds $\$ 5,000$, (in the case of $\$ 2,000$

டニニニニニニニニニニニニニニニニニニニニニー

Make the withholdings on expenditures for salaries and make the entire bimonthly for the ISR of its workers together with the bimonthly statement.

ニニニニニニニニニニニニニニニニニニニニニ

Discounts in the ISR to pay $100 \%$ during the first year, which will gradually decrease during the next L $-----\ldots$ ten years.

When the income received is less than the deductions for the period, taxpayers will consider the difference between the two items as deductible

Iーニニーニーーーー in the following periods.

They will not be obliged to present the DIOTs

whenever they present the information of the operations with their suppliers through the systems established by the SAT.

Registry, those who until December $\overline{31}, \overline{2} \overline{01} \overline{3}$ do not have another activity registered

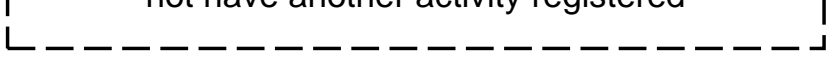

Figure 1 General characteristics of the RIF Source: own elaboration based on Vásquez, Ballesteros, Espinoza and Nagay, 2018; IMCP, 2015; Villasuso et al., 2015; Vázquez and Gutiérrez, 2019 


\section{RIF benefits}

Ruiz, Martínez and Arias (2017) mention that the RIF has been successful in attracting formality to microenterprises, the simplification and updating of tax regulations have allowed an increase in the taxpayer list as of 2014.

In this same sense, Manzanero and Castellanos (2016) present a series of advantages from the emergence of the RIF, among which are indicated:

- Ease to start a business or grow an existing one,

- $100 \%$ ISR payment discount during the first year and decreasing discounts for ten years,

- Deduction of expenses,

- Possibility of accessing credits for your company with better conditions,

- Option to become suppliers of large companies, and

- Access to housing loans, social security, health services provided by the IMSS.

Taxing under the RIF can allow the taxpayer to grow his business through the obtaining of credits from the private sector and government, since the formality of the business is an indispensable requirement to be credit subjects. Despite all the benefits that the new regime promises, it is important to mention that these are limited to the duration of this regime (ten years), some are not clearly seen for taxpayers and others decrease year by year (Barrera, 2017).

\section{Negative implications of the RIF}

After analyzing the scheme of the new regime, it is clear that the changes that are introduced are important especially for those who until 2013 taxed as REPECOS (Arguello, 2014), according to Dominguez, Face and Valencia (2014) some of the implications Negative for these taxpayers are:

The need to adapt a computer equipment with internet access for the issuance of invoices.
1.- Increase of tax obligations, which creates the need to hire accounting services.

2.- The ISR discounts are temporary, once the period indicated for these discounts has been fulfilled, the taxpayer must perform the tax calculation according to art. 111 and find out in full.

3.- Increase the payment of Value Added Tax immediately.

4.- In the long term there will be an increase in the contributions subject to the regime notoriously.

5.- Need to adopt electronic tools that are not always available to small businesses.

6.- Limitation to enter the regime for those taxpayers who provide services for those who require a professional degree, even if their income is equal to or less than 2 million pesos.

The establishment of the RIF meant for the taxpayers an increase in their fiscal obligations and in the administrative burden, since they must now invoice, submit bimonthly statements and keep accounts (Cisneros, et al., 2016), in addition to the small businesses being exceeded in terms of technological and fiscal knowledge, seeing the need to hire the services of an external accountant, which translates into an increase in business expenses, not to mention the difficult access to computer and internet (Manzanero and Castellanos, 2016 : Villasuso, et al., 2015; Barrera, 2017).

\section{Methodology}

This research has a qualitative exploratory approach according to the objective, limits and scope (Hernández et al., 2014), since it will allow to investigate this phenomenon that has been little studied in the city of Valle de Santiago, Guanajuato.

In order to obtain the information, the indepth semi-structured interview technique was used, applying in total 30 interviews to the business owners, since they are considered to be the people who make the administrative, accounting, fiscal and financial decisions, 
This interview included general questions of sociodemographic data, structural questions (requesting a list of concepts or categories), and questions to exemplify, which according to Hernández et al. (2014) serve to perform deeper explorations. A question guide was developed based on the review of the literature that includes questions grouped into the categories explained below.:

\begin{tabular}{|c|c|}
\hline Category & Items \\
\hline \multirow{3}{*}{ Fiscal } & Obligations under the RIF regime \\
\hline & $\begin{array}{l}\text { Taxes that are learned from the } \\
\text { hacienda }\end{array}$ \\
\hline & $\begin{array}{l}\text { Current tax legislation applicable to } \\
\text { the RIF }\end{array}$ \\
\hline \multirow{6}{*}{$\begin{array}{l}\text { Accounting- } \\
\text { Administrative }\end{array}$} & Method for accounting \\
\hline & $\begin{array}{l}\text { Administrative facilities that the RIF } \\
\text { has }\end{array}$ \\
\hline & $\begin{array}{l}\text { Competitiveness of the company } \\
\text { after registration to the RIF }\end{array}$ \\
\hline & $\begin{array}{l}\text { Business management when joining } \\
\text { the RIF }\end{array}$ \\
\hline & Accounting system used \\
\hline & $\begin{array}{l}\text { SAT applications for billing and } \\
\text { filing declarations }\end{array}$ \\
\hline \multirow[t]{6}{*}{ Financial } & $\begin{array}{l}\text { Company growth after joining the } \\
\text { RIF }\end{array}$ \\
\hline & $\begin{array}{l}\text { Expenses from its incorporation to } \\
\text { the RIF }\end{array}$ \\
\hline & $\begin{array}{l}\text { Amount of taxes that you learn from } \\
\text { the incorporation in the RIF }\end{array}$ \\
\hline & Billing Changes \\
\hline & Sales growth \\
\hline & Growth in the number of customers \\
\hline \multirow[t]{5}{*}{ Technological } & $\begin{array}{l}\text { Need to have a computer with } \\
\text { internet for compliance with tax } \\
\text { obligations }\end{array}$ \\
\hline & $\begin{array}{l}\text { Need for accounting system to } \\
\text { invoice and record operations }\end{array}$ \\
\hline & $\begin{array}{l}\text { Use of the applications provided by } \\
\text { the hacienda }\end{array}$ \\
\hline & $\begin{array}{llll}\begin{array}{l}\text { Preparation for } \\
\text { technologies }\end{array} & & & \text { use } \\
\end{array}$ \\
\hline & Media used by the hacienda \\
\hline
\end{tabular}

Table 1 Constructs that guided the collection Source: own elaboration

The following inclusion criteria were set to select the companies that participated in this study:

\begin{tabular}{|l|l|}
\hline \multicolumn{2}{|c|}{ Criteria } \\
\hline Geographic area & $\begin{array}{l}\text { Municipal head of Valle } \\
\text { de Santiago, Gto. }\end{array}$ \\
\hline $\begin{array}{l}\text { Year of registration to the } \\
\text { RFC }\end{array}$ & Prior to 2014 \\
\hline Current tax regime & RIF \\
\hline $\begin{array}{l}\text { Year of incorporation into } \\
\text { the RIF }\end{array}$ & 2014 \\
\hline
\end{tabular}

Table 2 Sample inclusion criteria Source: own elaboration

\section{Results}

The sociodemographic data of the interviewees shows that $33 \%$ have basic education (primary and secondary), $27 \%$ preparatory and only $27 \%$ of the sample have a Bachelor's and Postgraduate degree, another important demographic data is the age of the taxpayers, since the vast majority are adults and older adults and only a small portion of the sample (10\%) are young, with respect to the sociodemographic data of the business, these are mostly companies already established in the market, for the year in the that started operations are all classified as mature companies (see Table 3).

\begin{tabular}{|l|l|l|}
\multicolumn{1}{|c}{ Age } & \multicolumn{1}{c}{$\begin{array}{c}\text { Absolute } \\
\text { frecuency }\end{array}$} & \multicolumn{1}{c|}{$\begin{array}{c}\text { Relative } \\
\text { frequency \% }\end{array}$} \\
\hline $\begin{array}{l}\text { Young people 0 to } \\
\text { 10 years old }\end{array}$ & 4 & $13 \%$ \\
\hline $\begin{array}{l}\text { Mature more than } \\
\text { 10 years }\end{array}$ & 26 & $87 \%$ \\
\hline Total & 30 & $100 \%$ \\
\hline
\end{tabular}

Table 3 Age of the companies in the sample Source: own elaboration

Because of the number of workers they employ, they are all microenterprises and are mainly located in the commerce and services sector (see Table 4).

\begin{tabular}{|l|l|l|}
\hline Sector & \multicolumn{1}{|l}{$\begin{array}{l}\text { Absolute } \\
\text { frecuency }\end{array}$} & Relative frequency \% \\
\hline Industrial & 2 & $7 \%$ \\
\hline Commerce & 18 & $60 \%$ \\
\hline Services & 10 & $33 \%$ \\
\hline Total & 30 & $100 \%$ \\
\hline
\end{tabular}

Table 4 Sample companies sector Source: own elaboration

For the analysis of the positive effects that it has had for the taxpayers, passing from the REPECOS regime to the RIF presents a figure in which the results are grouped into four categories: "Fiscal factors", "Accountingadministrative factors", "Factors Financial "and" Technological factors". 


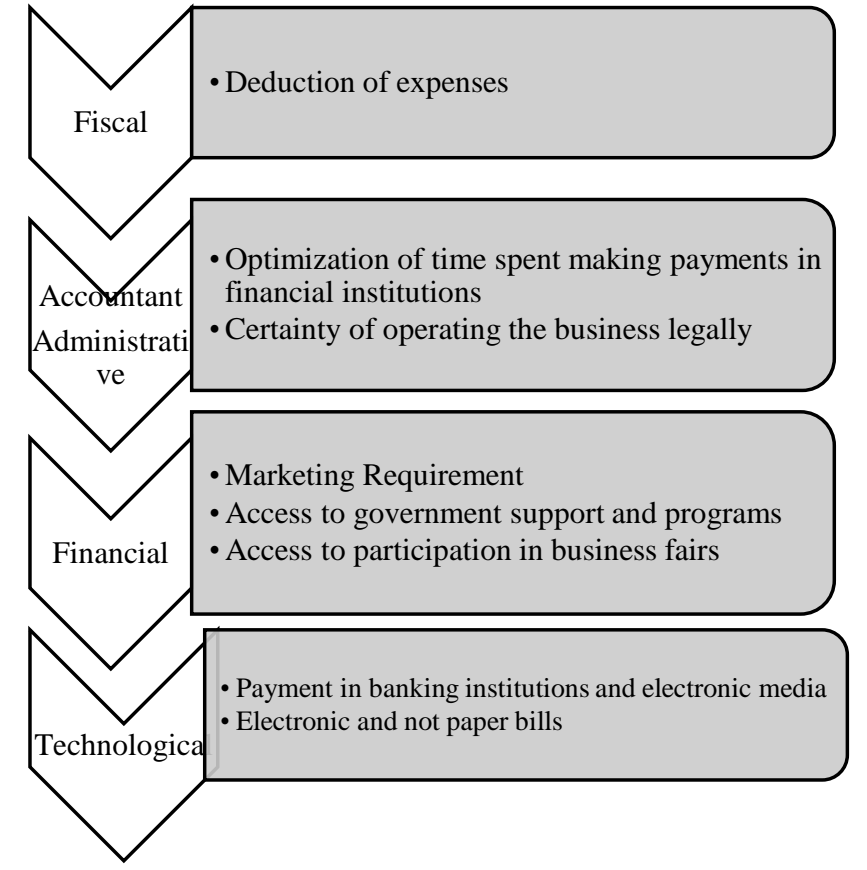

Figure 2 Benefits of RIF Source: own elaboration

As can be seen in Figure 2, the benefits that taxpayers receive are scarce, as regards tax issues, they only identify that with the new regime they can deduct expenses incurred in the business, although they must meet certain requirements. With regard to accounting and administrative benefits, they agree that the RIF has allowed them to save a lot of time that they used to spend in going to government offices and making long lines to make their payments. As for the financial advantages, the youngest companies are those that mention that enrolling in the RIF in addition to being a requirement for the marketing of their products and services, allows them to access business fairs in which it is possible to display their products, in addition to giving them the possibility of participating in government programs that seek to encourage the consolidation of small businesses; However, these benefits are not perceived in the same way by mature companies, since they do not see economic and financial growth in their business because they are contributors to the RIF. Finally, they perceive that electronic invoicing and payment of contributions in banking institutions are an important advance in terms of the use of technology, although they recognize that they are not prepared to make adequate use of ICT, either because they do not have the resources financial to acquire a computer equipment with the Internet or because they are elderly people who are not very familiar with the use of technological applications, however, they agree that the new regime is more modern and tries to incorporate technology to support compliance with the Fiscal obligations.
With respect to the disadvantages, a Figure with the description of the effects that small businesses perceive in this study on the tax incorporation regime is included below.

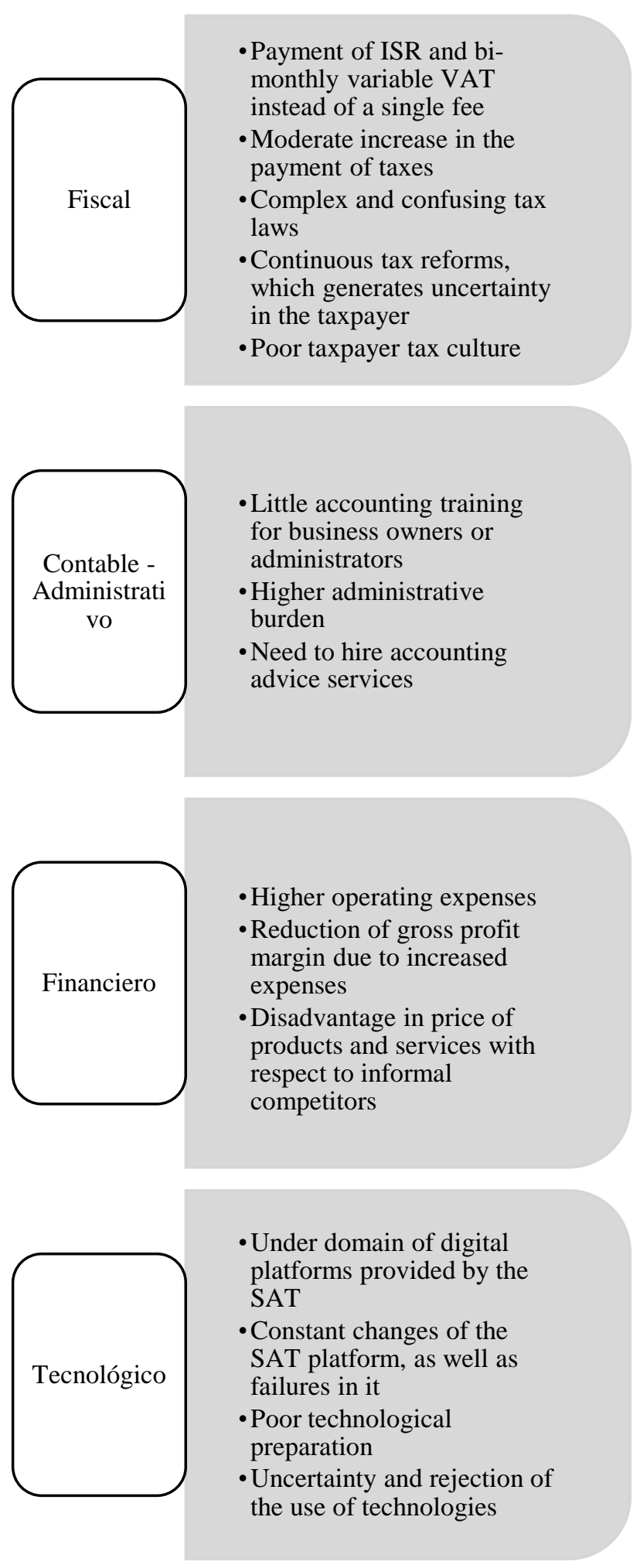

Figure 3 Effects of the RIF Source: own elaboration 
It can be seen that taxpayers perceive tax disadvantages derived from the incorporation into the new regime, among which are: the payment of ISR and VAT variant on a bimonthly basis instead of a single fee as they were used, which translates into a moderate increase in the amount of taxes paid; fiscal laws seem complex and confusing, not to mention that tax reforms are constant, which creates uncertainty about the future of their obligations.

It is worth mentioning that in general the interviewees have a very superficial overview of the operation of the RIF, which is why they keep accounts with an Accountant outside the business, who is responsible for registering operations, submitting declarations and, in most cases, invoicing when the business is requested, that is; that the owners of the stores consider that the administrative burden is greater due to the lack of training and the lack of knowledge they have about the billing programs, and to avoid complications, they only keep the manual registration of income to later provide this information to the accountant They are completely unaware of what accounting programs their data is processed in and they do not know the means used by their accountant for billing.

It is noteworthy that all respondents said they had contracted the services of an external accountant for the fulfillment of their tax obligations, and few taxpayers who invoice on their own account, which coincide precisely with those who have a level of professional training of Bachelor and Postgraduate, so there could be a relationship between the level of education and the ability to carry out some fiscal-accounting functions.

Among the financial effects are mentioned: an increase in operating expenses and therefore a reduction in gross profit margin, since they cannot increase the sale price of their products and services to cover additional expenses, as this would mean losing customers and sales, so they feel disadvantaged compared to competitors who are not registered; Among the main additional operating expenses are those derived from the payment of accounting services, billing program and payment of bimonthly tax.
Finally, in the category of technological affectations, the low dominance of the taxpayers of the digital platforms provided by the SAT, as well as the constant changes that the authority implements in the platform and failures, which confuses the taxpayers.

In general, business owners have little technological preparation, except for those who have a level of education equal to and above Bachelor, that is, although they have the ICT tools to facilitate accounting and tax activities, they do not have the ability to use and implement them for the benefit of the business, so there is uncertainty and rejection of the use of technologies, especially in older taxpayers and less academic preparation.

\section{Conclusions}

Although the Fiscal Incorporation Regime emerged as an initiative of the executive to reduce tax evasion and encourage small businesses to move into formality, the reality is that this regime has brought positive and especially negative implications, which have mainly affected the MIPyMES companies that are the engine of the Mexican economy.

Faced with such controversy, this research managed to clarify a little the situation experienced by microenterprises in the region by identifying the main affectations and benefits that businesses in the city of Valle de Santiago, Guanajuato have, derived from their incorporation into the RIF.

With respect to the stated objective, the results reflect the owners' indifference to the incentives that the government promises with this regime, since the benefits have been a little more on the operational side with the tools made available by the SAT and especially the comfort of the taxpayer to make tax payments in banking institutions instead of the traditional system that followed the REPECOS regime. 
Financial benefits have been few, not to mention null, since the level of sales and customers has not been affected either positively or negatively, taxpayers know that the growth of their business depends on offering products and services with more quality to customers, at a better price than their competitors, so that registered taxpayers have a perception of disadvantage with respect to those informal competitors, since the latter, unfairly, can offer products at better prices when compared to formal businesses, which must consider within their operating expenses the payments derived from being registered in the taxpayers register (professional services of public accountant, tax payment, billing program, among others).

This regime seeks to train the taxpayer in administrative and operational matters, with the aim of preparing him to migrate to a more stringent regime, however, it is worrying, the reduced knowledge and preparation for the use of technologies (including the computer and internet) that They say they have business owners, this low technological preparation could be explained first, by the weak professional training of taxpayers, since $33 \%$ of respondents only have basic education (primary and secondary), and a second important factor is the age, since those young taxpayers were those who expressed a greater willingness to use technology and therefore the RIF.

This low preparation regarding the use of technologies explains why taxpayers do not use the "My accounts" application that the Ministry of Finance and Public Credit has arranged for accounting and billing of the RIF and they are not sure what the accounting program is You use your accountant to carry out these activities.

Another aspect to highlight is the low tax culture on the one hand of small business owners, since they have a vague idea of the taxes they are subject to, tax laws, administrative facilities applicable to the RIF and in general the implications of this regime, leaving everything in the hands of the accountant; and on the other hand of the clients of the businesses, since they rarely request an invoice for the purchases they make or the services they receive, for which reason the invoicing has not increased considerably for the companies.
Taxpayers are not aware that the RIF is a transitory scheme, and that after completing the ten-year period they will go to the General Regime of Physical Persons, thereby increasing their tax burden and obligations, they only perceive the effects in the short term, leaving side the tax, accounting and financial future of your business.

It is concluded that the tax reform is not entirely negative, the intention of the government to reduce informality has been met, since taxpayers express their concern to be up to date with their obligations and avoid fines by the Ministry of Finance, however, the execution seems to have setbacks, the population is not prepared for the changes that were introduced after the reform, there is no fiscal culture on the part of small business owners, nor enough technological preparation to fulfill on their own obligations.

\section{References}

Arguello, F. (2014). Nuevo Régimen de Incorporación Fiscal de las Personas Físicas. Boletín Fiscal, 3, Cd. de México: IMCP.

Barrera, D. (2017). Análisis del impacto financiero del Régimen de Pequeño Contribuyente en su transición al Régimen de Incorporación Fiscal en el ISR e IVA por el periodo 2014 - 2016. Tesis de Licenciatura, Universidad Autónoma del Estado de México, México.

Castro H. J., Carrillo, A., Cortés, S., del Rivero, A., Serrano, M. E. y Santana, M. M. (2011). Estudio de Evasión Fiscal en el Régimen de Pequeños Contribuyentes. México: ITESM.

Cisneros, J. L., Bravo, L. M., Valenciana, P., Carrillo, S. y Bustamante, A. C. (2016). Formalidad o cautividad fiscal mediante el Régimen de Incorporación Fiscal en México, Revista Global de Negocios, 4 (5), 27-40.

CCPM (2018). Régimen de incorporación fiscal 2018. Boletín de Investigación de la Comisión de Desarrollo Profesional Fiscal, 68, Cd. de México: CCPM.

DOF (2014). Segunda Resolución de modificaciones a la Resolución Miscelánea Fiscal para 2014. Recuperado de 
http://www.dof.gob.mx/nota_detalle.php?codig $\mathrm{o}=5351246 \&$ fecha $=04 / 07 / 2014$

DOF (2015). Decreto por el que se reforman, adicionan y derogan diversas disposiciones de la Ley del Impuesto sobre la Renta, de la Ley del Impuesto Especial sobre Producción y Servicios, del Código Fiscal de la Federación y de la Ley Federal de Presupuesto y Responsabilidad Hacendaria. Recuperado de http://www.dof.gob.mx/nota_detalle.php?codig $\mathrm{o}=5415878 \&$ fecha $=18 / 11 / 2015$

Domínguez, P., Rostro, P. y Valencia, M. (2014). Repeco la muerte anunciada. Ciencias Administrativas y Sociales, 5, 280-287.

Hernández, R., Fernández, C. y Baptista, P. (2014). Metodología de la investigación (6a ed.). México, D.F., México: McGraw-Hill Interamericana.

IMCP (2015). Régimen de Incorporación Fiscal. Boletín de la Comisión de Investigación Fiscal, 24, Cd. de México: IMCP.

Cámara de Diputados del H. Congreso de la Unión. (2014). Ley del impuesto sobre la renta. Recuperado de http://www.diputados.gob.mx/LeyesBiblio/pdf/ LISR_301116.pdf

Lomelí, P. (2015). La desaparición del Régimen de Pequeños Contribuyentes en la Reforma Fiscal de 2014: análisis y perspectivas. Recuperado de https://www.pan.org.mx/wpcontent/uploads/downloads/2015/12/630.pdf\#p age $=12 \&$ zoom $=100,0,94$

Manzanero, A. R. y Castellanos, A. A. (2016). Impacto fiscal a pequeños contribuyentes: el caso de la reforma fiscal del 2014. Ciencia Administrativa, (1), 137-146.

Ruiz, D. C., Martínez, J. y Arias, F. Políticas públicas para enfrentar la informalidad. Recuperado de http://bibliodigitalibd.senado.gob.mx/handle/12 $3456789 / 3663$

Vásquez, A., Ballesteros, L. L., Espinoza, R. y Nagay, J. (2018). Análisis del impacto del régimen de incorporación fiscal en las Pyme de la Ciudad de Piedras Negras, Coahuila. Red de Estudios Latinoamericanos en Administración y Negocios, 2 (2), 50-59.
Vázquez, D. A. y Gutiérrez, P. (2019). Efectos tributarios del Régimen de Incorporación Fiscal (RIF) en México: 2014 - 2017. Revista de Estudios en Contaduría, Administración e Informática, 8 (21), 48-60.

Villasuso, V. M., Bojórquez, A. L. y De los Santos, I. A. (2015). Factores que influyen en el cumplimiento fiscal en el régimen de incorporación fiscal. México: ANFECA. 